European journal of American studies

Special Issue: Sound and Vision: Intermediality and American Music

\title{
Looking Hip on the Square: Jazz, Cover Art, and the Rise of Creativity
}

Johannes Voelz

\section{OpenEdition}

\section{Journals}

Electronic version

URL: https://journals.openedition.org/ejas/12389

DOI: $10.4000 /$ ejas. 12389

ISSN: 1991-9336

Publisher

European Association for American Studies

Electronic reference

Johannes Voelz, "Looking Hip on the Square: Jazz, Cover Art, and the Rise of Creativity", European

journal of American studies [Online], 12-4 | 2017, Online since 22 December 2017, connection on 08 July 2021. URL: http://journals.openedition.org/ejas/12389 ; DOI: https://doi.org/10.4000/ejas.12389

This text was automatically generated on 8 July 2021.

Creative Commons License 


\title{
Looking Hip on the Square: Jazz, Cover Art, and the Rise of Creativity
}

\author{
Johannes Voelz
}

1 Jazz is usually considered a musical genre with its own history, consisting of stylistic innovations and developments that range from New Orleans jazz of the early twentieth century to various forms of fusion and jazz rock of the 1970s and beyond. ${ }^{1}$ The historical trajectory leads from folk art to commercial popular culture, onward to modernist high art, and finally to pluralized eclecticism. But next to this view of jazz as a musical and artistic evolution, there has for a long time been an alternative perspective that embeds jazz in a spectrum of African American cultural expression. From that perspective, jazz is part of a "black aesthetic" or "blues aesthetic," which runs through African American painting, dance, photography, literature, and even architecture. $^{2}$

2 From this latter perspective, jazz would lend itself to being analyzed as a phenomenon that is "intermedial" or even "transmedial"-technical terms that since the 1990s have had a steep career in media and literary studies, initially in Germany and subsequently internationally. Intermediality broadly refers to "relationships between media and is hence used to describe a huge range of cultural phenomena which involve more than one medium" (Rippl 1), whereas transmediality, in the usage of most scholars, refers to "phenomena that are non-specific to individual media (motifs, thematic variation, narrativity) and which appear across a variety of different media" (Rippl 12). There is a reason why jazz, or rather the critical tradition of incorporating jazz into a blues or black aesthetic, has only rarely come into contact with discussions of intermediality and transmediality. ${ }^{3}$ Claims of an African American idiom pervading different media are driven first and foremost by a political agenda that reacts to the systemic cultural marginalization of black artists and the African American experience more generally. The study of inter- and transmediality, on the other hand, has either pondered philosophical questions, such as (to cite philosopher Sybille Krämer) the "epistemological condition of media-recognition [Medienerkenntnis]" (82, cited in, and translated by, Rajewsky 48), or it has explored analytical and formalist challenges that 
arise-in the case of intermediality-from the endeavor to account for the ways in which media, for all their specificity, interact in particular works. By and large, the study of inter- and transmediality has not been invested in the cultural politics of representation, identity, or recognition by any group of people, whereas proponents of the black aesthetic mostly seem to find it beside the point to formalistically and terminologically belabor the claim of cross-medial continuities of black expression beyond rather vague and impressionistic references to pervasive aesthetic principles such as call-and-response and improvisation. ${ }^{4}$

Rather than bring together both of these approaches-i.e., the study of the black aesthetic and the study of intermediality in its present form-I will introduce a perspective on intersecting medialities that both of these critical traditions lack. This is the perspective of cultural sociology, which, in my deployment, comprises two facets: first, an awareness of the networks of cooperation involved in the act of artistic creation, including the institutional structures of marketing and distribution. Such networks extend the individual work or performance into a host of different media, embedding sound in visual culture and textual repertoires. Following American sociologist Howard S. Becker, I call this cooperative model of artistic production an "art world." The second facet of cultural sociology I bring to bear on my approach opens up a historical perspective on the place that a specific art world inhabits in the larger society at a particular time, and on the structural impact that art world has on society. Following German sociologist Andreas Reckwitz, I describe the impact of the jazz art world on American society as contributing to the rise of a creativity dispositif that has flourished, in the last three decades, into a full-fledged "aesthetic capitalism."

4 Approaching the inter- and cross-medial phenomenon of jazz from these two sociological perspectives has a key advantage over both the story of the musical evolution of jazz and the emphasis on jazz as an exemplar of a black aesthetic: it provides an explanation for how jazz flourished in a relatively short span of time, roughly between 1945 and 1965, and why it since then has become increasingly relegated to a cultural niche. The musicological perspective has given us the terms and descriptors of how the music evolved, and how one new school followed the next within only a few years. (In the firmly established sequence of jazz styles, modern jazz began with bebop, followed shortly after by cool jazz, hard bop, modal jazz, free jazz, and fusion.) This musicological perspective alone cannot account for the cultural and economic relevance the music gained and lost between the rise of bebop and the turn to free jazz. On the other hand, the politicized account of jazz as the crowning achievement of a black aesthetic is even more strongly, indeed self-consciously, ahistorical in that it aims to emphasize a continuity of black expression despite historical changes and the various different musical genres emerging over time. This perspective is emphasized by Amiri Baraka's much-quoted phrase of "the changing same," which he defined as "THE BLUES IMPULSE transferred... containing a race, and its expression. Primal (mixtures... transfers and imitations). Through its many changes, it remained the exact replication of The Black Man In The West" "“The Changing Same" 180 , ellipses in original).

5 I bring analytical methods of cultural sociology to bear on the intermedial dimension of jazz not so as to deny the existence of African American aesthetic principles running through different fields of expression. Rather, I do so because the problem animating this essay-namely, how to explain the rise and fall of jazz in the twenty years after 
World War II-requires an historical perspective that can account for something as elusive as the relevance and vibrancy of jazz in U.S. culture at large. I will begin by outlining, in the briefest manner, the "creative revolution" (Thomas Frank) that led to the establishment of what Andreas Reckwitz calls the creativity dispositif. Subsequently I will make a few suggestions of how the jazz art world came to play a central part in this larger development (showing this in detail requires a book-length study). For this purpose, I will provide an initial sketch (again, a more comprehensive account is beyond the scope of this article) of how jazz became linked visually to two different cultural spheres, which, for all their differences, routinely intersected: on the one hand the world of fine arts, and on the other hand that of commercial art. At the center of my analysis will be some more or less famous specimens of LP cover art by photographers and designers such as William Claxton, Reid Miles, Andy Warhol, and Esmond Edwards. To varying degrees, these artists-and their many colleagues, both famous and unknown-straddled the worlds of fine arts and commercial art. It is no coincidence that they provided their artistic services for the production of jazz records, considering that at the moment of its highest cultural impact, the position of jazz was precisely located between commercial and high art-with the various actors involved in the jazz art world pulling in both directions at once.

\section{The Rise of Creativity}

6 Beginning in the 1990s, sociologists, cultural and media studies scholars, and economists began to track how Western societies have tended, in the past few decades, to elevate "creativity" to a core cultural value, thus releasing it from the cultural margins and promoting it to the very heart of the structures of contemporary capitalist society. Media studies scholar John Hartley, who, along with Richard Florida, Thomas Frank, Lawrence Lessig, Terry Flew, Angela McRobbie, and others, has been at the forefront of this line of scholarship, argues that

there is an argument for re-purposing the very idea of 'creativity' to bring it into closer contact with the realities of contemporary commercial democracies. 'Art' needs to be understood as something intrinsic, not opposed, to the productive capacities of a contemporary global, mediated, technology-supported economy. Both art and creativity need to be looked for within the living practices of a multicultural, multi-valent population that is neither aristocratic nor dumb. (8-9)

7 Hartley's proposal to view art as intrinsic rather than opposed to the economy bespeaks a post-Fordist constellation that increasingly organizes cultural, economic, and social relations. His suggestion is analytical as much as it is symptomatic of the place contemporary society has allotted to creativity.

Being concerned with the reign of creativity already in place, Hartley's focus on the contemporary leads to the question of how creativity could rise to its present position. Andreas Reckwitz has recently worked out a systematic genealogy of this development. His account is as far-reaching as it as is persuasive, but it necessarily needs fleshing out in the details. For the United States, the prominence of the jazz art world from the early 1950 s to the mid-1960s is an essential chapter of the story, omitted by Reckwitz. But the point of bringing in Reckwitz is not to fill in the gaps of his account but rather to use his perspective in order to get a better grip on the vicissitudes of jazz in American culture. 
9 Reckwitz argues that since the eighteenth century, Western societies have undergone a process of social aestheticization. As part of this process, the aesthetic-by which Reckwitz means neither aesthetic categories like the beautiful, nor sense perceptions in general (as denoted by the classical term aesthesis), but rather "perception [that] is an end in itself and refers to itself" (11)-became tied to novelty, and innovation itself increasingly took an aesthetic form: "the creativity dispositif reorients the aesthetic towards the new while at the same time orienting the regime of the new towards the aesthetic" (9). ${ }^{5}$ The bundling of both of these terms ought not to be taken for granted. Historically, aesthetics has often been unrelated to the new (for instance, in the everyday aesthetics of ritual) and innovation has long been regarded as a rational process that is adverse to sense perceptions for their own sake (for instance, in technological innovation). Reckwitz thus charts the historical process by which the joint focus on the new and aesthetic traveled from marginal niches-particularly in the field of art-to the center of social organization, ultimately reaching the point where it became a systemic social organizing principle. In this final stage, social aestheticization has become what Reckwitz, following Michel Foucault, calls a creativity dispositif.

Reckwitz divides this process of social aestheticization into four phases. He calls them 1) preparation, which he dates from the late eighteenth to the late nineteenth century, 2) formation, which "covers the period from around 1900 to the 1960s," 3) crisis and concentration, which he locates between the 1960s and 1970s, and 4) domination, which describes the developments since the 1980s (30). According to Reckwitz, in the "phase of formation"-again, located from around 1900 to the 1960s-"bits and pieces of different social and cultural practices emerge here and there in various social fields, promoting (aesthetic) novelty and its creative production" (31). Among them are the beginnings of the "creative industries" of fashion, design and advertising, the field of audio-visual mass media and the concomitant rise of creative stars from film, music and the art scene. However, in this phase these various agents of social aestheticization have not been bundled to shape the core of the social structure. This changes in the following period, during the sixties and seventies: Individual elements of the creative complex previously existing in isolated social pockets now attract wider attention, occasionally becoming radical and giving rise in their turn to varyingly radical alternatives to the dominant forms of the economy, art, self-technologies and urbanity. Historically, jazz's period of bloom I am concerned with falls right between these two phases. In this sense, jazz is a transitional phenomenon.

\section{Jazz as an Art World}

11 In what follows, I will sketch out a few elements of the development of jazz from 1945 to 1965 from a perspective that is intermedial insofar as it comprehends jazz as an "art world." Howard S. Becker, in his seminal study of the same title (1982), defined the concept of the art world as the "network of people whose cooperative activity, organized via their joint knowledge of conventional means of doing things, produces the kind of art works that art world is noted for" (x). From this perspective, all artistic production is cooperative-a totally solipsistic act of creation would result in unintelligibility. The level of cooperation and degree of organization, however, changes from art world to art world. In music, it includes anything from the makers of musical instruments to the suppliers of the material to be played, and reaches all the way to the 
networks needed to stage performances, make recordings, and distribute them. Even the listener becomes an essential element for the social realization of an art world.

Becker's approach, which might be seen as a Chicago-school precursor to networkactor-theory, pursues several implicit agendas. First, it redefines the role of the artist, placing emphasis on the network of people involved, instead of singling out one creator, as if he or she acted in a vacuum. At the same time, the theory is acute to the hierarchies involved in such networks, which usually become apparent through the differentiation between who counts as artist and who is considered support personnel. This hierarchy translates into a practical distinction: from the perspective internal to a given art world, the essential artistic personnel cannot be replaced, whereas the support personnel is interchangeable.

In applying Becker's model to jazz, I take up Becker's own frequent references to the jazz world (they reflect his inside perspective as a former professional jazz musician) and further build on sociologist Paul Lopes's study The Rise of a Jazz Art World (2002). Focusing on the time period from the 1930s to the 1960s with the intent of understanding more fully the jazz renaissance of the 1950s, Lopes "looks not only at the impact of this art world on jazz music and jazz musicians, but the different meanings and associations non-artists brought to jazz as an art form during this period" (5). In his book, this effectually translates into a study of jazz criticism, with some considerations of changing performance venues and the recording industry. But since the concept of the art world radically expands the concept of artistic creation, it ought to be expanded even further so as to include marketing, design, advertisement, journalism, distribution, and ultimately the reception of jazz. In particular, acts of embedding musical sounds in visual discourses deserve critical attention. It matters, for instance, how jazz takes on its own visual vocabulary through the design of album sleeves, promotional publications, and press coverage. To a degree, these components of the production process are fully professionalized craft practices that can be taken over by any number of specialized professionals. But if the audience is kept in mind as an integral part of the artistic process, then the visual dimensions of the music begin to play a crucial role because these dimensions begin to shape the cultural meaning that makes the final artistic product appealing in the first place. (The same can be said for jazz criticism, but this aspect has been studied extensively, not least by Lopes himself; see also Gennari.)

Becker's model-which is self-consciously commonsensical, but which suggests ramifications that often are at odds with the central assumptions we bring to art (particularly high art)-also raises awareness of the crucial importance of artistic conventions for the practical realization of art worlds. As a rule, the more complex the network becomes, the greater importance is accorded to conventions. Instead of seeing conventions as a standardizing force of the culture industry, Becker regards them as taking over the role of facilitating and coordinating cooperation: "Conventions make collective activity simpler and less costly in time, energy, and other resources; but they do not make unconventional work impossible, only more costly and difficult" (35).

This leads to the recognition that the regime of radical artistic innovation requires specific institutional conditions. Most typical is a funding structure capable of supporting the extra costs incurred by radically changing the game. An example would be New Music compositions that require the musicians to learn to read the composer's individualized notation system before they can perform the piece-an extra effort that 
costs time and money. Another way of facilitating radical innovation may come from start-up business structures that have not yet reached a level of routinized organization and thus operate on the basis of experimentation and gathering of bestpractice experience. For example, independent record labels operating outside of the well-rehearsed structures of major companies are convention-bound in some respects but are forced to experiment in others. As we will see, the entry of such companies into the music industry indeed helped jazz flourish after World War II. Moreover, such companies were instrumental in pushing the process of social aestheticization to the next level. Ultimately, however, such innovative practices of the art world of jazz built on the continuous reliability of musical conventions established in the 1940s, even when the spirit of innovation was prized musically as well. As I show in the next section, these musical-and ultimately visual-innovations of the 1940 s themselves grew out of changes in the commercial infrastructure of the jazz art world of the time.

\section{The Image of Bebop: The Artful, the Hip, and the Popular}

16 As the swing era declined in popularity and economic profitability in the late 1930s, the future of jazz looked uncertain, particularly for black dance band musicians, who suffered most from the restrictions imposed on the music industry by World War II. From the late 1930s to the mid-1940s, some predominantly African American professional musicians, the majority of whom were much in demand in black big bands with national name recognition, began to forge a new musical style during late-night jam sessions in Harlem. Played by small combos rather than big bands, this style was based on fast tempos, intricate rhythms, complex chord progressions, augmented and diminished harmonies, angular melodic lines (whether improvised or used as actual melodies), and extended space for improvisation as well as for rhythmic interplay.

Initially, this music was not geared to public performance; rather, the professional big band musicians who gathered at these after-hour clubs used jam sessions as experimental laboratories. Only beginning in 1943, as employment opportunities in black dance bands dried up, did these musicians take their new small-combo music to the clubs of $52^{\text {nd }}$ Street in midtown Manhattan. The new sounds quickly caught on, and they proved to be moderately profitable. A new cabaret tax imposed on live performances had left a loophole for instrumental music, which made improvised small-combo jazz competitive (see DeVeaux, Birth 285). In addition, a recording ban of the American Federation of Musicians (AFM), which had stopped all recording activities of unionized musicians in 1942, came to a partial settlement in 1943, when Decca, one of the three major record companies, gave in to the AFM's conditions. With the other two major labels-Victor and Columbia-still holding out, independent recording labels began to sprout up. In effect, the recording ban thus managed to break open the monopoly of the recording industry, mobilizing the field with the emergence of new companies. (The majors meanwhile focused on vocal pop music, since singers were not organized in the AFM.) As we will see, such independent record labels would prove to be a key factor in making jazz a flexible, creative industry.

18 As World War II ended, record companies no longer faced material shortages, while, on the other hand, the economic downturn of the postwar years made big bands financially untenable. It was at this point that some of the small independent labels 
caught on to the new music played in the clubs of $52^{\text {nd }}$ Street. Initially, the new jazz appeared as a viable product. Perhaps the major advantage the new type of jazz had over swing was that it was artist-focused. Companies did not need to hope for popular hits-always a high financial risk in the nobody-knows-economies of the cultural field (see Caves 3-5)-but could rely on the name recognition of leading musicians. In order to help turn the complex and challenging new music into a profitable commodity, it needed to be packaged so that-in accordance with the rules of an aestheticized consumption economy-what was sold was not merely recorded sound, but the suggestion of a whole lifestyle. The focus on individual artists was a helpful prerequisite, since it allowed attaching jazz to the romantic tradition of the individual artist hero who lived, and styled, his life according to the mandates of his art-who could, in other words, be encountered as the embodiment of his sound, and who could be listened to as the sound of a particular style of life.

This identification of the jazz improviser with the image of the artist was forged visually through the work of photographers like William Gottlieb and Herman Leonard. In the early years, their photos were not yet used for record covers-using photographs on record covers became common only in the mid-1950s-but they appeared, in Gottlieb's case, in such music publications as Down Beat and were used, in Leonard's case, "as promotional material by record companies including RCA Victor, Decca, Capitol, Mercury, and Verve" (Pinson 35).

Leonard's photographs are particularly significant for the stylization of the jazz improviser as an artist rather than entertainer, and they have had a lasting impact on the image of jazz. ${ }^{6}$ In his signature style, Leonard depicted individual musicians on stage, surrounded by smoke, lit by two strobe lights, one positioned in the back, one in front of the musician. The dramatic lighting is underlined by laser-sharp focus of the textures of musicians' skin, instruments, and clothes, by diagonal lines subdividing the image (sometimes the result of a tilted camera angle), and by a sharp differentiation between a soloist in the foreground and accompanying musicians or audience (often also composed of well-known musicians) in the background. In such scenes, Leonard showed musicians either playing in performance or pausing and reflecting on their music. Whereas before, jazz musicians had been presented with standardized headshots, Leonard presented them as serious, concentrated artists, dressed in stylish, classy clothes, and shrouded in clouds of smoke that functioned metaphorically and metonymically at once-as signs of artistic creativity and inspiration, and as traces of the underground nightlife venues at which the new music was played. These images, in other words, made a claim for the recognition of the music as a serious art and simultaneously expressed a subcultural authority of hipness. ${ }^{7}$

Link 1: Herman Leonard: Dizzy Gillespie, 1948

http://hermanleonard.com/graphics/images/_full/DZG04.jpg

However, in order to make a bid for popular and commercial success, more was needed than a generalized association with artfulness and hipness. The new jazz needed to plug into the emerging star system, and it needed a marketable name or label. Dizzy Gillespie provided both. One of the scat-syllables he used on his recordings-bebopprovided the catchy name for the new music. And he himself-in part thanks to his relentless publicity efforts-became, as Benjamin Cawthra writes, "the face" of bebop: "Due to Gillespie's puckish personality and distinctive fashion sense, white journalists made him a symbol of the new music" (76). 

other bebop innovators became venerated hipster artists, it was Gillespie who become a living icon, providing a look that could be copied by followers. In 1948, the magazine Metronome named Gillespie's ensemble "Band of the Year." The encomium of editor Barry Ulanov emphasized not the music but the look Gillespie had made trendy:

All over America, young boppers who had never worn a hat donned the Dizzy cap: young boppers, who had never been able to raise a sufficient hirsute covering to prove their age, struggled with chin fuzz in an attempt to build the Gillespie goatee: young boppers with their own little bands began to lead from the waist and the rump; some, with perfect eyesight, affected the heavy spectacles. (17-18)

Bebop as represented by Gillespie was self-consciously personality-driven, artistic, subcultural, and popular at the same time. These elements, however, hardly led a harmonious co-existence. Claiming bebop as art was a political move in that it effectively asked for the recognition of African American cultural achievement based on modernist aesthetic criteria of innovation. Ever since, jazz has been burdened with the problem of securing artistic legitimation, and the problem of artistic legitimation in turn became tied to the inequalities imposed by a racist society. A profile of Dizzy Gillespie by Richard O. Boyer, published in The New Yorker in July, 1948, made the connection between racial politics and the modernist high art status of bebop explicit by citing the association of traditional jazz with Uncle Tomism:

Bebop, according to its pioneer practitioners, is a manifestation of revolt. Eight or ten years ago, many Negro jazz musicians, particularly the younger ones, who were sometimes graduates of music conservatories, began to feel, rightly or wrongly, that the white world wanted them to keep to the old-time jazz. They held the opinion that the old jazz, which they called 'Uncle Tom music,' was an art form of a meeker generation than theirs. They said that it did not express the modern American Negro and they resented the apostrophes of critics who referred to them, with the most complimentary intent, as modern primitives playing an almost instinctive music. (30)

But the claim for high art status could also run into conflict with the aims of a racial politics if it entailed the adoption of the aesthetic standards of European (white) high culture. Such contradictions were faced, for instance, by the Modern Jazz Quartet, or, a little later, by Nina Simone, when she bemoaned not being allowed a career as a classical concert pianist but "only" as a performer of blues, jazz, or soul. (The longer story of the conflict between a black cultural politics and the aspiration to established high culture standards reaches back all the way to the debates around W.E.B. Du Bois's program of racial uplift.)

Similar conflicts run through the understanding of bebop as a subculture. On this level, bebop represented the marginalized culture of African Americans and also supplied a model of hip stylization for (self-identified) outsiders of all types-hence the strong identification of Beat writers like Jack Kerouac with bebop musicians, or the slogan "Bird Lives!" painted onto sidewalks and walls in New York City after the death of Charlie Parker in $1955 .^{8}$

Jazz of the bebop years can be seen, in fact, as the historical origin of hipster-culture, and white writers of the time-most explicitly, with a few years' delay, Norman Mailer, in his essay "The White Negro" (1957)-helped foster the meaning of the black musician as a hipster outsider-figure, who responded to the conformism of mainstream culture with a quasi-existentialist attitude and a style of knowing defiance. The point is not to blame white Beat writers for romanticizing and depoliticizing the cultural styles of

European journal of American studies, 12-4 | 2017 
black bebop pioneers but to take seriously the fact that bop musicians like Gillespie, without intending to do so, established a mode of stylization that employed, to borrow from Reckwitz, a "hip/square-code," which distinguished "between original and conventional," rather than simply "old and new" (109). Reckwitz sees the hip/squarecode as a change within a longer historical trajectory of the fashion world. "No longer fettered by strict class divides... this distinction [between original and conventional] doesn't apply primarily to status groups; rather, it focuses on successful individuality (and is secondarily extendable to lifestyle groups)" (109). Here we see how the hipster idea came into conflict with the expression of the life of a marginalized minority. Gillespie may have been one of the original hipsters, but to the extent that his style reflected the realities of racist discrimination, it clearly did not fit easily with the aim of successfully achieving one's individuality-although it arguably did pursue that aim as well. The conflict becomes pronounced by the fact that the hip/square-code, by its very logic, contains an inbuilt obsolescence. How could the bebop style be a fashionable expression of the black experience if, understood as a fashion, it was destined to become outmoded? As a result of the music's popularization, sudden obsolescence was, in fact, precisely what happened to bebop a few years later, thus bringing to the fore a dilemma for the political project implied in the bebop subculture.

This brings us to the final element-bebop's (short-lived) popularity. For bebop, the code of hipness cut two ways: it created an avant-garde position ahead of the crowd that lent itself to seeking recognition as a serious, modernist art, but it also-because of its emphasis on style-sought being emulated, at least by those in the know. Like any pop culture phenomenon, bop sought distinction and popularity at once. What mattered was that popularity was achieved on the aesthetic terms of the jazz world, without suffering the dilution resulting from commercialization. This ambiguity complicates the well-worn narrative that bebop musicians replaced the model of the entertainer with that of the artist. Bebop musicians, as Scott DeVeaux has emphasized throughout his path-breaking book The Birth of Bebop, had all been successfully integrated into the swing music industry before it faltered. Indeed, in aspiring to gain a wider audience with the help of (tele-)visual self-marketing campaigns, bebop musicians like Gillespie followed in the tradition of making a modernist art that could appeal to broad audiences-though with ultimately limited success. Bebop musicians were not averse to the popularization strategies of the music industry so long as they built on the musical aspirations of musical hipness. However, bebop did fail to fulfill the major recording companies' hopes for large sales numbers and consequently was abandoned by the industry and the broader audience after a few short years.

In more senses than one, bebop left an important legacy. While most jazz historians emphasize that the musical innovations of bebop turned into the conventions of mainstream jazz within just a few years (a claim that is certainly correct), another way of understanding the legacy of bebop is to identify it as the uneasy combination of the artful, the hip, and the popular. Thanks to this combination-and thanks to the conflicts of the various elements just outlined-bop laid the ground for the culturally influential spurt of jazz innovations that lasted from the mid-1950s through the mid-1960s, a time period that soon came to be called the "New Jazz Age." 


\section{Designing Music in the "New Jazz Age”} radio. research shows: companies. (228-230) and popular.

Though the popularity of bebop had substantially waned by 1950, jazz did not therefore decline as a whole. On the contrary, in the 1950s jazz saw an unexpected phase of growth and innovation. Jazz musicians were in demand in recording studios on the East and West Coast and in performance venues across the country. Next to jazz clubswhich continued to face economic instability despite the boom-new types of performance spaces across the country opened up for jazz musicians, including concert halls, festival, college campuses, and high schools. Non-specialist national media began to report regularly on jazz-on the music as much as on its boom-in print, TV, and

In 1954, both Time Magazine and Life Magazine reported on what they described as the rebirth of jazz, paying particular attention to the white protagonists of the West Coast scene, such as Dave Brubeck, whom Time put on its cover in November, 1954. Time proclaimed a "New Jazz Age" (Time, November 8, 1954, quoted in Lopes 226), and Life announced that there was "New Life for U.S. Jazz: Young Innovators Share Boom with Old Hands." As the Life writer pointed out, "Its fans see and hear the ranking players at work in small clubs and big concerts. But it is largely the records, selling at seven times the rate they were selling five years ago, that have given jazz the widest audience in its lavish history" (Life, January 17, 1954: 42, quoted in Lopes 227).

The boom in jazz recordings had to do with the rise of independent companies in the aftermath of World War II. While the discovery of jazz by the major companies was a sign that around the music there had grown a sustainable market, independent productions far outnumbered those by the "big four" (Columbia, Decca, RCA-Victor, and Capitol) and played a crucial part in driving aesthetic innovation. As Paul Lopes's

By 1955, the number of jazz records produced were ten times the number produced in $1950 \ldots$. The big four, however, continued to play mostly a reactive role in producing jazz. The majors did sign important figures in modern jazz, but only after they had proven themselves on independent jazz labels.... In 1961-62, for example, Down Beat listed 188 jazz ensembles with 78 percent recording for one of 60 independent labels and the other 22 percent with one of the major record

The virtual recording frenzy of those years depended to a considerable extent on the technical innovation of the LP record-around 1950, most companies began producing ten-inch vinyl records, and by 1955 the twelve-inch record had become the industry standard. This allowed for a significantly longer playing time, which fundamentally changed recorded jazz. Only now could recordings reflect the performance practice of extended solos. This enhanced the possibility for improvisers to become known for their individual style of improvisation, which, in turn, deepened the understanding of jazz as a music that deserved to be called art, but that was simultaneously trend-setting

Significantly, the twelve-inch format also posed a new problem-and a new opportunity -for record companies: the enlarged record sleeves needed to be designed more carefully than had been common so far. Even during the ten-inch years in the early 1950s, independent labels mostly did not yet design their sleeves other than in the most perfunctory manner. On several of Miles Davis's ten-inch albums, Prestige printed the 
same small photograph in low quality, each time in a different single-color tint. Compare, for instance, the covers of The New Sounds (1951) and Blue Period (1953).

Link 2: Miles Davis: The New Sounds (1951), Prestige. Cover design and cover photo: unknown https://upload.wikimedia.org/wikipedia/en/8/8b/MilesNewSounds.jpg

Link 3: Miles Davis: Blue Period (1953), Prestige. Cover design and cover photo: unknown https://upload.wikimedia.org/wikipedia/en/0/01/Blue_period.jpg

Only with the invention of the twelve-inch record, then, did the jazz art world begin to branch out, with force, into the visual arts, turning records into aesthetically designed material products with new possibilities to tie the music to a visual rhetoric, and ultimately to the image of a lifestyle. Record producers began hiring photographers for cover shoots and liner photographs, and they began to employ designers to give their record sleeves a recognizable look.

The new design challenge required independent companies-who usually employed no more than a handful of staff members-to create working conditions conducive to experimentation. Riverside, which was founded by Orrin Keepnews and Bill Grauer in 1953-at a point when leading independent labels on the East Coast and West Coast were just beginning to leave an imprint on the look of jazz-put conscious effort into allowing its artists to come up with new creative ideas. As Benjamin Cawthra writes in Blue Notes in Black and White (2004), the most meticulous study of jazz cover art to date:

Keepnews and Grauer hired Paul Bacon-a writer, illustrator, designer, and contributor to the [magazine] Record Changer-to design for Riverside, paying by the cover. Keepnews and Grauer gave Bacon and his colleagues Harris Lewine, Ken Braren, and photographer Paul Weller a 'free hand,' Bacon recalled. 'We did what we wanted.' (211)

On the West Coast, too, design and photography came to be embraced as a key element of music production. Los Angeles, though not nearly as central to jazz as New York City, bustled with recording activity. Independent jazz labels like Pacific Jazz and Contemporary recorded both traveling East Coast musicians and locals. The local scene recorded by these companies included both white and black musicians, but the companies turned white band leaders, such as Brubeck, Chet Baker, and Gerry Mulligan, into the scene's biggest stars, thus indirectly fostering an association of West Coast jazz with white musicians and East Coast jazz with black musicians. In part, this association came about because West Coast labels recognized early that they could capitalize on their regional affiliation by giving their recordings a different look, and this meant visually taking jazz out of the world associated with urban black music. (A different sound was more difficult to come by, though the media insisted that musicians in California-read: white musicians-played in a more orderly and intellectual manner and put more emphasis on composition than their East Coast colleagues.) Though calling West Coast jazz "white" and East Coast jazz "black" is more narrow-minded than the actual music produced on both coasts, it is crucial to emphasize that the increased importance of the visual dimension of the jazz art world was from the start involved in the frictions of a racist, overwhelmingly segregated society.

41 Reflecting the extraordinary standing of visuals, Richard Bock, the founder of Pacific Jazz Records-one of the pace-setting independent labels from L.A.-hired photographer William Claxton as art director, and soon after even promoted him to partner of the company. As Claxton remembers it, "[f]ollowing several successful 
covers, Dick [Bock] asked me to join the organization as Art Director and "Chief Photographer'; a month later I was made a partner in the company" (Claxton, "Clickin' with Clax" 7). Claxton, like the artists working for Riverside, was encouraged to be continuously innovative, which led to his choice of motifs that differed as drastically as possible from the existing jazz image (which concentrated on musicians in smoke-filled clubs, and was forged, as we have seen, by artists like Herman Leonard and William Gottlieb during the bebop years):

Dick Bock... pushed me to come up with more and more new ideas for the record cover designs. I put Chet Baker and his quartet on a boat for Chet Baker and Crew; I shot Bud Shank and Bob Cooper with children and Bush Shank with the funny papers; I mounted Shelly Manne, Barney Kessel and Ray Brown on carousels of a merry-go-round; I put Shorty Rogers in a space helmet and up a tree house; and I shot musicians on the sandy beaches and in vintage cars... It became my signature to photograph jazz musicians in unlikely places. But what to do next? (Claxton, “Clickin' with Clax" 10)

Goldblatt, cover photo: William Claxton https://img.discogs.com/B82PycWkLfnvvmqQ5MQtt2Xf9I8=/fit-in/600x600/ filters:strip_icc():format(jpeg):mode_rgb():quality(90)/discogs-images/ R-3486855-1385591579-9263.jpeg.jpg

\section{Jazz as a Creative Industry: Amateurs and Innovators}

In part because of its small-scale infrastructure, in part because of the modernist aesthetic principles of innovation insisted on by the recording artists, and in part 
because the jazz art world, as Lopes points out, had "no centers of authority" (218), jazz was becoming an industry that ran not only on the image, but on the structures, of creativity. Independent record companies thus anticipated the so-called "creative revolution" that beginning in the 1960s increasingly restructured American capitalism into an aesthetic capitalism. Aesthetic capitalism differed from the older type of rationally organized, "Fordist" capitalism in that it began to rely on "work activities that demand the constant production of new things, in particular of signs and symbols -texts, images, communication, procedures, aesthetic objects, body modifications-for a consumer public in search of originality" (Reckwitz 2).

In fact, these flexible recording start-ups may be seen as a model adopted by cuttingedge American advertisement agencies-like Doyle Dane Bernbach (DBB)-when these firms began to leave behind the then-regnant advertising conventions, which Thomas Frank has described as the "Cold War orthodoxy of prosperity, progress, and consumer satisfaction" (47). This advertising orthodoxy was mirrored by a rigid and hierarchical division of labor, in which management ruled and the artists routinely fulfilled orders. As Frank has shown, in the 1960s ad agencies consciously began freeing up their creative personnel from a rigid command structure so as to facilitate the creation of advertising campaigns that were different, original, and innovative. Bill Bernbach, of DBB, in particular stressed that advertising was not a science but an art, and could only become an art if admen could create unfettered by bureaucracies and hierarchies. Indeed, he transposed to his agency the practice that independent record companies had used since the mid-1950s: he gave his artists a free hand.

51 The differences, of course, cannot be overlooked. Advertising agencies were large companies holding multi-million dollar accounts. Independent jazz labels were niche companies so small-and economically insignificant-that a Fordist organizational structure (a semblance of which could be found among major record companies) was not even an option. This also explains how creativity and artfulness could at times be indistinguishable from amateurishness. Some companies, like Prestige, took some time until they realized the importance and potential of the visual design of their product. Prestige founder Bob Weinstock took many of the cover photos himself and even took over design responsibilities, with results that hardly qualified as the new look of hip. A good example is the cover for Sonny Rollins's album Work Time, from 1955.

Link 11: Sonny Rollins: Work Time (1955). Cover design and cover photo: Bob Weinstock https://upload.wikimedia.org/wikipedia/en/1/11/Work_Time.jpg

The photograph shows Rollins with saxophone in mouth, shot dramatically from below. The image aims to establish Rollins's colossal presence (a metonymy of his large tenor sound-his musical trademark). One year later, for what would become Rollins's most famous Prestige recording, Weinstock repeated this motif with yet another one of his photographs and elevated it to become the record's explicit theme. The title: Saxophone Colossus. In the Work Time image, the camera angle and the lighting led to the unfortunate result that the largest part of Rollins's head is blacked out. Moreover, the right half of his face is blocked by the saxophone. If Weinstock's image was mediocre, he arguably was even less adept at designing the cover. The giddy, overly playful lettering in green, white, and black - with each sideman being listed in a different font, scrawled along the right margin - clashes with the effect of sheer force to which the image aspires. 
At the request of sound engineer Rudy van Gelder, Weinstock soon took greater care of the visual dimension of his records (Marsh and Callingham, Coast to Coast 22). Only at first glance should it surprise how quickly the company moved from substandard cover art to cutting-edge avant-gardism: in a minimally structured economy like the jazz art world, the line between the two was remarkably thin. Weinstock hired skilled photographers (several of whom also overtook overall production tasks) like Esmond Edwards, Ray Avery, and Don Schlitten. Edwards, in particular, helped bring a different look to what had quickly become one of the leading East Coast hard bop labels. He captured musicians outside of the studio, without instrument, as can be seen, for instance, on Miles Davis's album Workin' with the Miles Davis Quintet (1956), released just as Davis was transferring over to the major company Columbia Records.

Link 12: Miles Davis: Workin' with the Miles Davis Quintet (1956). Cover design and cover photo: Esmond Edwards

https://upload.wikimedia.org/wikipedia/en/f/f8/MilesDavis_Workin.jpg

Weinstock also hired freelance designers Tom Hannan and Reid Miles (who later became best-known as the in-house designer of Blue Note Records shortly after). Miles, in turn, hired artists for individual records that did not feature photographs, among them, on several occasions, Andy Warhol. Even when Warhol's input was minimal, it was strikingly effective and helped turn the attention to the cover for its own sake. For Thelonious Monk's album Monk (1954), Warhol provided calligraphic handwriting of the featured players' names. Next to the capital letters MONK, set in Futura and covering almost the entire cover square, Warhol's input was so small that it was hardly noticeable at first sight, but this only added to the self-consciously stylish tension arising from the combination of ornate hand-lettering with minimalist print-font. ${ }^{9}$

Link 13: Thelonious Monk: Monk (1954), Prestige. Cover design: Reid Miles [and Andy Warhol, unattributed]

http://cps-static.rovicorp.com/3/JPG_1080/MI0002/395/MI0002395179.jpg?

partner=allrovi.com

Throughout his career, Warhol designed close to sixty sleeve designs. ${ }^{10}$ Though many of them preceded his breakthrough as an innovator of pop art, even in his commercial output Warhol crossed the border between professional support person and artist in his own right. For the Monk cover, he had his mother Julia Warhola provide the handwritten letters, and later he returned to her hand-lettering for several other covers, thus effectively turning the device into a signature element of his style.

Link 14: Moondog: The Story of Moondog (1957), Prestige. Cover design: Andy Warhol [unattributed hand-lettering by Julia Warhola]

https://upload.wikimedia.org/wikipedia/fi/c/ca/The_Story_of_Moondog.jpg

15: Tennessee Williams: Reading from the Glass Menagerie, The Yellow Bird And Five Poems (1960), Caedmon. Cover design: Andy Warhol [unattributed hand-lettering by Julia Warhola] https://s3.amazonaws.com/vf-images/wp-content/uploads/2014/06/6-tennesseewilliams1.jpg

In 1956, the year he designed the Monk cover, his sleeve designs also began to feature his signature, further amplifying the status of his contributions as works of art in their own right. Thus, the jazz art world and the fine art world began to intersect, and it became a question of perspective who provided the support for whom. What started casually in Warhol's jazz illustrations during the mid-1950s became the key maneuver 
of his most famous record sleeve design, The Velvet Underground \& Nico, from 1967. Instead of depicting the band, Warhol placed a banana at the center of the cover and added his signature (or rather, what was supposed to look like a mechanically massreproduced signature), thus overtly and ironically claiming autonomous art status for the cover design. In effect, Warhol turned the record cover into a pop art version of Marcel Duchamp's urinal. While Duchamp had used a signature to claim art status for an industrial ready-made, Warhol repeated the gesture for an image that undeniably served illustrative (i.e., non-autonomous) purposes. By that time, Warhol's idea of signing cover designs had traveled a considerable distance towards conceptual maturity. By contrast, his first jazz cover wearing his signature-designed in 1956 for the Prestige album Trombone by Three by J.J. Johnson, Kai Winding, and Benny Greenwas marred by the fact that Warhol seemingly mistook a trombone for a clarinet or soprano saxophone. This may, of course, also have been a subversive gesture. In any case, the jazz art world was not ready to deal with it. The cover design was only used as an alternate version-which makes it all the rarer today.

Link 16: J.J. Johnson, Kai Winding, Benny Green: Trombone by Three (1956), Prestige. Alternate cover. Cover design: Andy Warhol

http://vf-images.s3.amazonaws.com/wp-content/uploads/2014/06/trombone-bythree.jpg

Link 17: The Velvet Underground and Nico: The Velvet Underground \& Nico (1967), Verve. Cover design: Andy Warhol

https://upload.wikimedia.org/wikipedia/en/0/0c/Velvet_Underground_and_Nico.jpg

\section{High Art, Ordinary Life, and the Jazz Image: The Case of William Claxton}

Considering Warhol's cover designs along with Claxton's cover photographs, two intersecting visual strategies of the booming jazz art world become noticeable: one forged links to other spheres of the art world; the alternative route decoupled the jazz image from its older associations with a twilight subculture located in smoky night clubs, and instead brought jazz into the good life of what economist John Kenneth Galbraith, in the title of his 1958 bestseller, had termed "the affluent society."

Though it makes sense to distinguish between these two avenues for analytical reasons, in actual fact they often intersected. Claxton's work is a good example. No one was more instrumental in giving jazz the look of popular everyday stylishness, yet Claxton -as we shall see below-was also keen on placing jazz in the context of visual fine art. Even when integrating jazz into everyday life, Claxton searched for a balance that kept the association of jazz with creativity in place. Racially integrated groups of jazz musicians playing on the beach or on sailboats radically undermined traditional jazz connotations of illicit transgression. Yet the very act of showing musicians in these settings-not in a documentary manner, but rather in self-reflexive arrangementsattested to a sense of originality, which encompassed not only the photographer but the depicted protagonists as well. Claxton's imagery, in other words, made jazz safe for everyday consumption and for its incorporation into an all-American lifestyle without displacing the hip/square-code. 
By necessity this had a racial dimension: in a largely segregated society, ${ }^{11}$ bringing jazz into the mainstream also meant bringing it into "white" American life. Race, however, remained a subtext in these images, since what made this life "white" is also what made it Californian, or Western. And it was this regional dimension that Claxton's photographs emphasized. These primarily regional, and secondarily racial, connotations of his attempts to make jazz all-American also involved aligning the music with the dominant myths of American popular culture.

Claxton's most famous record cover, from 1956, shows East Coast tenor saxophone star Sonny Rollins in the Mojave Desert wearing a Stetson hat and an empty holster for a six-shooter (instead of a gun, he is holding his saxophone). Rollins came up with the idea for the cover shoot himself-the album was entitled Way Out West-and rather than aligning himself with John Wayne, he later explained that he had aimed to impersonate black cowboy actors from the 1930s, such as Herb Jeffrey-who was a dual reference point for Rollins, since he was also a musician and later in his career sang in Duke Ellington's band under the name of Herb Jeffries (cf. Cawthra 190-191). While some listeners-particularly African Americans-were probably hip to the reference, for other listeners the image must have simply related to mainstream Westerns. In its bluntness, the association was unusual, but by no means impossible. If jazz musicians could be depicted golfing and diving, why couldn't they be cowboys as well? ${ }^{12}$

Link 18: Sonny Rollins: Way Out West (1956), Contemporary. Cover design: unknown, cover photo: William Claxton

https://upload.wikimedia.org/wikipedia/en/4/44/Sonny_Rollins-

Way_Out_West_\%28album_cover\%29.jpg

69 Though not necessarily by intention, Claxton also emphasized the connection of jazz to mainstream American popular culture through his photographic work outside of jazz. His pictures-later published in thematically ordered books-helped launch trumpeter Chet Baker as a photogenic icon. ${ }^{13}$ He shot him in concert, in the studio, in front of cars, at home, with various girlfriends, and surrounded by groupies-and used largely the same photographic language the he also employed for his extended work with film star Steve McQueen (though the images of McQueen, as a rule of thumb, are a bit more candid and intimate). Claxton's visual vocabulary of turning a male artist into a charismatic, mysterious, vulnerable, and overtly sexualized icon could be applied to many different subjects, whether jazz musicians or film stars, so long as their developed image displayed the right mix of sensitivity and subliminal toughness. It should be noted that this type of masculinity was racially coded as well. Despite his memorable portraits of Ornette Coleman and John Coltrane, Claxton never created an intense photographic relationship with any African American male comparable to that with Baker and McQueen.

70 Link 19: William Claxton: Chet Baker with Helima, Redondo Beach, 1955

https://static1.squarespace.com/static/

57eba5686b8f5be752cb5b77/57ebcf1c197aea92a6c44a75/581c5f1e197aeaf96c68606e/

1478617190962/Chet+Baker+with+Helima\%2C+Redondo+Beach\%2C+1955.JPG?

format $=750 \mathrm{w}$

71 Link 20: William Claxton: Steve McQueen Sitting Cross-Legged in Beverly Hills, 1962

https://static1.squarespace.com/static/

57eba5686b8f5be752cb5b77/57ebd13c03596ed76b29687b/58348c3e37c5812128e8b94b/

1479839865791/stevemcqueen+-+2015.jpg?format $=750 \mathrm{w}$ 
William Claxton: Ornette Coleman, Hollywood, 1959

https://static1.squarespace.com/static/

57eba5686b8f5be752cb5b77/57ebcf1c197aea92a6c44a75/581e9885e58c62bd0980a088/1478616062427/

Ornette+Colman.jpg?format $=750 \mathrm{w}$

Link 22: William Claxton: John Coltrane at the Guggenheim, NYC, 1960

https://static1.squarespace.com/static/

57eba5686b8f5be752cb5b77/57ebcf1c197aea92a6c44a75/581c5f2246c3c4918971b8e3/1478364034453/

John+Coltrane+at+the+Guggenheim\%2C+NYC\%2C+1960.JPG?format $=750 \mathrm{~W}$

74 The portrait of John Coltrane, taken in 1960 in front of a Franz Kline painting at the newly opened Frank Lloyd Wright building of the Guggenheim, is a memorable example of Claxton's attempt to stress the art status of jazz via association with the visual arts. In contrast to Sonny Rollins, who came up with the idea for being photographed as a cowboy, the idea of associating Coltrane with an abstract expressionist painter was Claxton's. As he recalled in 2005,

I took the picture when I was traveling through the United States with Joachim Ernst Berendt for our book Jazz Life. Joachim, a very organized German, had all these interviews lined up for us. I had read in the paper about the opening of the new Guggenheim, and I wanted to see it. So I took Coltrane there. He told me he had never consciously been to a museum. I didn't get any permission beforehand to shoot at the museum. Coltrane was walking around with his saxophone. I put him in front of the Kline painting-which was a favorite of mine-and simply took the picture. (Voelz, Interview)

Claxton's image is unusually tricky in its composition. Whereas art photographersparticularly recent artists such as Thomas Struth-tend to show viewers of paintings along with the paintings they view, Claxton captures Coltrane, whom we get to see from the side, as he intently looks straight ahead at what is presumably an artwork on the wall he faces. We, the viewers, on the other hand, get to see the Kline painting behind Coltrane's back. It is cropped on the top and bottom of the photograph and thus seems of enormous proportions. Instead of allowing us to create an imaginary relation between ourselves and Coltrane (which would require that both parties look at the same artwork), Kline's painting, from our perspective, enters into a direct visual dialogue with Coltrane. It is as if he were physically drawn into the Kline painting towering beside him. The result is a striking metonymy. It isn't that Coltrane's art is being compared to abstract expressionism. Rather, the art he embodies becomes physically engulfed by the painting, while the very shape of his body becomes an ensemble of gray-scale forms that interact with those of the painting. Claxton's emphasis on the physical relation between Coltrane and the Kline painting may be regarded as an homage to the bodily nature of both art forms. This common denominator was even more pronounced in Jackson Pollock's drip paintings, which became associated with jazz on a regular basis, perhaps most famously on the cover of Ornette Coleman's album Free Jazz (1961).

Several years before taking Coltrane to the Guggenheim, Claxton worked towards associating jazz with the fine arts as part of the regionalist agenda of Pacific Jazz:

Since the name West Coast Jazz had become so firmly entrenched with the music media, I came up with an idea that would further the importance of an art movement that was going on in the Los Angeles area at that time. The art galleries were flourishing with the talents of local artists.... Dick Bock and I commissioned several of these artists (Bob Irwin, Keith Finch, Sueò Serisawa, and John Altoon). We would either give the artist a recording of a specific jazz artist or group to work 
with, or we would actually have the group play for the artist at his studio to

'inspire' the painter. (Claxton, “Clickin' with Clax" 11) flourished in a specific constellation that began to change during the 1960s. This constellation was characterized by an expansion of the norm of creativity from the sphere of art to ever more social and economic arenas. Reckwitz has described the 
creativity dispositif's phase of formation, which he dates from approximately 1900 to the 1960s, as a conglomerate of phenomena that includes "the beginnings of the 'creative industries' of fashion, design and advertising, the organizational discourse around... innovation economics, a positive psychology defending artistic genius against its stigmatization as pathological, ... the rise of interest in creative stars from film, music and the art scene, ... and a far-reaching dissolution of the boundaries within and around artistic practices and aesthetic objects while breaking down the myth of artistic individuality" (31). These developments, Reckwitz concludes, "cause the aesthetic and creativity to break out of their containment within the classical, bourgeois conception of art" (31).

Without mentioning jazz, Reckwitz's description captures many of the characteristic components of the jazz art world I have discussed in this essay. As the attention which record labels paid to cover designs demonstrates, the jazz art world participated in the emergence of the creative industries; while it did not directly participate in a discourse of innovation economics, actors in the jazz art world nonetheless reflected on how to create conditions most conducive to the demand for constant innovation; by lifting jazz out of a nightlife scene with shady associations, jazz played a key role in freeing the image of the artist from the older connotations of the pathological; in the jazz world, musicians began to turn into stars and sometimes directly overlapped with the visual culture of the Hollywood star system; and finally, while seeking high art status, jazz crossed the boundaries that keep art forms separated from one another and guard the difference between artistic and non-artistic domains of life.

Crucially, during the high tide of jazz, the creativity dispositif was beginning to break out of its narrow artistic bubble. Art promised to supply a model for an aestheticized life. Due to its complicated racial, economic, and artistic history, jazz came to incorporate and embody that trajectory. This helps explain how jazz could become, for a short span of time, such a popular and culturally relevant phenomenon. Jazz promised the availability of a creative and original way of life at a moment when many Americans perceived U.S. culture to be meek, conformist, stifled by corporate overorganization (encapsulated in the image of the "man in the gray flannel suit") and lacking aesthetic richness in everyday life. For jazz to be able to play this transitional role, the bebop triad of artfulness, hipness, and popularity became an opportunity rather than a burden.

By the same token, however, this also begins to suggest why jazz-though present as a niche phenomenon in American, indeed, global cultural to this day-began to lose its luster at some point in the 1960s. Usually the explanation offered rests on purely musical aspects: While the modernist ethos of innovation drove jazz into a level of complexity that made the music unrelatable for wider audiences, popular music became redefined in such a way that jazz lost its foothold in the popular. Such an account is not incorrect, but the diminishing appeal and cultural relevance of jazz beginning in the 1970s can better be explained by the structural transformation effected by the onset of the next phase of the process of social aestheticization. As creativity became the norm both of an entire counterculture and a type of capitalism that increasingly became aesthetic, the tenuous balance between artfulness, hipness, and popularity that had explained the success of jazz a few years earlier lost its appeal. By now, creativity no longer needed to be transported from the arts into everyday life. It had already arrived there. The world of music exemplifies this: Popular music was no 
longer a commercial music aiming for hits that met the widest possible taste, but had by now incorporated the hip/square code and thus adopted an avant-garde dimension of its own. The album The Velvet Underground \& Nico, with its close ties to pop artist Andy Warhol, is a telling instance. What had been popular music was now pop music.

Henceforth, the creativity dispositif could operate, and further develop, in a whole range of social fields, including the arts, advertising, management, politics, etc. Jazz, however, was stuck with its capacity to facilitate the expansion of creativity from the field of art to the everyday. It had succeeded as a form of expression that could transport creativity to the cultural center. To this day, it continues to perform this transport in an almost ritualistic manner. This gives jazz a lasting appeal to those invested in the jazz tradition. But for the culture as a whole, this redundancy has led to the increasing cultural irrelevance of jazz and its art world.

\section{BIBLIOGRAPHY}

Baraka, Amiri [Leroi Jones]. “The 'Blues Aesthetic' and the 'Black Aesthetic': Aesthetics as the Continuing Political History of a Culture" [1990]. Digging: The Afro-American Soul of American Classical Music. Berkeley: U of California P, 2009. 19-28. Print.

---. "The Changing Same (R\&B and New Black Music)." Black Music. New York: William Morrow, 1967. 180-211. Print.

---. Blues People. New York: Morrow Quill Paperbacks, 1963.

Becker, Howard S. Art Worlds. Berkeley: U of California P, 1982. Print.

Boyer, Richard O. "Bop." The New Yorker, July 3, 1948. 28-37. Print.

Caves, Richard E. Creative Industries: Contracts Between Art and Commerce. Cambridge, MA: Harvard UP, 2000. Print.

Cawthra, Benjamin. Blue Notes in Black and White: Photography and Jazz. Chicago: $\mathrm{U}$ of Chicago P, 2011. Print.

Claxton, William. "Clickin' With Clax: A History of Pacific Jazz Records." William Claxton and Hitoshi Namekata. Jazz West Coast: Artwork of Pacific Jazz Records. Tokyo: Bijutsu Shuppan-Sha, 1992. 6-11. Print.

---. Steve McQueen. Cologne: Taschen, 2004. Print.

---. Young Chet. Munich: Schirmer/Mosel, 1993. Print.

DeVeaux, Scott. "Bebop and the Recording Industry: The 1942 AFM Recording Ban Reconsidered." Journal of the American Musicological Society 41 (1988): 126-165. Print.

---. "Constructing the Jazz Tradition: Jazz Historiography" [1991]. The Jazz Cadence of American Culture. Ed. Robert O’Meally. New York: Columbia UP, 1998. 483-512. Print.

---. The Birth of Bebop: A Social and Musical History. Berkeley: U of California P, 1999. Print.

Flew, Terry. The Creative Industries: Culture and Policy. London: Sage, 2012. Print. 
Florida, Richard L. The Rise of the Creative Class and How It's Transforming Work, Leisure, Community and Everyday Life. New York: Basic Books, 2004. Print.

Frank, Thomas C. The Conquest of Cool: Business Culture, Counterculture, and the Rise of Hip Consumerism. Chicago: U of Chicago P, 1997. Print.

Freeman, Don. "Bock Becomes First To Fuse Modern Art, Jazz LP Covers." Down Beat 23.5 (March 7, 1956): 14. Print.

Gennari, John. Blowin' Hot and Cool: Jazz and Its Critics. Chicago: U of Chicago P, 2006.

Hartley, John. “Creative Industries.” Creative Industries. Ed. John Hartley. Malden: Blackwell, 2005. 1-40. Print.

Jarrett, Michael. “The Tenor's Vehicle: Reading Way Out West.” Representing Jazz. Ed. Krin Gabbard. Durham: Duke UP, 1995. 260-282. Print.

Krämer, Sybille. "Erfüllen Medien eine Konstitutionsleistung? Thesen über die Rolle medientheoretischer Erwägungen beim Philosophieren.” Medienphilosophie: Beiträge zur Klärung eines Begriffs. Eds. Stefan Münker, Alexander Roesler, and Mike Sandbothe. Frankfurt am Main: Fischer, 2003. Print.

Lessig, Lawrence. Remix: Making Art and Commerce Thrive in the Hybrid Economy. New York: Penguin, 2009. Print.

Lock, Graham, and David Murray, eds. The Hearing Eye: Jazz and Blues Influences in African American Visual Art. New York: Oxford UP, 2009. Print.

Lock, Graham, and David Murray, eds. Thriving on a Riff: Jazz and Blues Influences in African American Literature and Film. New York: Oxford UP, 2009. Print.

Lock, Graham, and David Murray. "Introduction: The Hearing Eye.” The Hearing Eye: Jazz and Blues Influences in African American Visual Art. Eds. Graham Lock and David Murray. New York: Oxford UP, 2009. 1-18. Print.

Lopes, Paul Douglas. The Rise of a Jazz Art World. New York: Cambridge UP, 2002.

Marsh, Graham, and Glyn Callingham, eds. Coast to Coast: Album Cover Art from New York to Los Angeles. London: Collins and Brown, 2011. Print.

Marsh, Graham, and Glyn Callingham. "Foreword." Coast to Coast: Album Cover Art from New York to Los Angeles. Eds. Graham Marsh and Glyn Callingham. London: Collins and Brown, 2011. Print.

McRobbie, Angela. Be Creative: Making a Living in the New Culture Industries. Cambridge: Polity P, 2016. Print.

Murray, Albert. Stomping the Blues. New York: Da Capo P, 1976. Print.

Ouelette, Dan. “Bird Lives Forever: Modern Graffiti Makes Its Debut in New York.” The Huffington Post, August 24, 2016. Web. Last viewed September 2, 2017. Print.

Pinson, K. Heather. The Jazz Image: Seeing Music Through Herman Leonard's Photography. Jackson: UP of Mississippi, 2010. Print.

Rajewsky, Irina 0. "Intermediality, Intertextuality, and Remediation: A Literary Perspective on Intermediality.” Intermédialités 6 (Autumn 2005): 43-64. Print.

Reckwitz, Andreas. The Invention of Creativity: Modern Society and the Culture of the New. Cambridge: Blackwell, 2017. Print. 
Rippl, Gabriele. "Introduction.” Handbook of Intermediality: Literature, Image, Sound, Music. Ed. Gabriele Rippl. Berlin: De Gruyter, 2015. 1-31. Print.

Robinson, Jason. "The Challenge of the Changing Same: The Jazz Avant-garde of the 1960s, the Black Aesthetic, and the Black Arts Movement." Critical Studies in Improvisation / Etudes critiques en improvisation 1.2 (2005). Web. Last viewed Sept. 1, 2017.

Stearns, Marshall. The Story of Jazz. New York: Oxford UP, 1956. Print.

Stein, Daniel. Music is My Life: Louis Armstrong, Autobiography, and American Jazz. Ann Arbor: U of Michigan P, 2012. Print.

Ulanov, Barry. “Band of the Year: Dizzy Gillespie.” Metronome, January 1948: 17-18. Print.

Voelz, Johannes. “'Blues and the Abstract Truth': Or, Did Romare Bearden Really Paint Jazz?" The Hearing Eye: Jazz and Blues Influences in African American Visual Art. Eds. Graham Lock and David Murray. New York: Oxford UP, 2009. 194-218. Print.

---. Interview with William Claxton. Savoy Hotel Berlin, September 27, 2005.

\section{NOTES}

1. This narrative can be traced back to Marshall Stearns's The Story of Jazz (1956). For a critical perspective, see Scott DeVeaux, "Constructing the Jazz Tradition."

2. Graham Lock and David Murray write that "close links between African American painting and music have been evident since the early years of the twentieth century. Aaron Douglas, a pioneering figure of black modernist art, recalled that when he set out in the mid-1920s to create a new, distinctive African American aesthetic in his painting, his Harlem contemporaries looked to black music and dance to provide the model: 'At that time, pleas could be heard on all sides for a visual pattern comparable to, or rather expressive of, the uniqueness found in the gestures and body movements of the Negro dance, and the sounds and vocal patterns as found in the Negro song"' "Introduction" 1). The idea of a "black aesthetic" was later promoted by the Black Arts Movement. See, for instance, Amiri Baraka [Leroi Jones], Blues People and his later essay "The 'Blues Aesthetic' and the 'Black Aesthetic': Aesthetics as the Continuing Political History of a culture." See also, from a different perspective that emphasizes the "idiomatic authenticity" of the blues tradition, Albert Murray, Stomping the Blues. For an insightful discussion, see Jason Robinson, "The Challenge of the Changing Same: The Jazz Avantgarde of the 1960s, the Black Aesthetic, and the Black Arts Movement."

3. One of the exceptions is Daniel Stein's study Music is My Life: Louis Armstrong, Autobiography, and American Jazz, which brings to bear an intermedial and transmedial method on its subject. It is no coincidence that Stein is a German scholar.

4. For an attempt to substantiate the cross-medial references and techniques between jazz, the visual arts, and literature, see the collections The Hearing Eye and Thriving on a Riff, both edited by Graham Lock and David Murray. See also my “'Blues and the Abstract Truth': Or, Did Romare Bearden Really Paint Jazz?," which critiques the black aesthetic approach on the grounds that it neglects the dimension of media-specific aesthetic experience.

5. I have Americanized the spelling of the English translation of Reckwitz's book for the sake of consistency.

6. His photos gained their prominence only later on, in the late 1980s, when they were rediscovered and became recognized as fine art in and of themselves (see Pinson). During the late 
forties, Leonard's photographs traveled in narrow circles. As Benjamin Cawthra writes, "Besides semi-regular publication in Metronome and one or two other niche magazines, the only public display of his 1948 and 1949 Royal Roost and Birdland images occurred in the clubs themselves" (72).

7. The point here is not to reiterate a prejudicial differentiation between high art and popular art, but to reconstruct how the high/low-divide operated as a historically specific discourse in the creation of a particular image of jazz.

8. As Dan Ouellette writes, "Bird Lives appeared everywhere in the city, from subway platforms to brownstone walls, in chalk, black crayon and even pressurized paint cans" (unpaginated).

9. Reid Miles claimed the overall design as his own-indeed, he called it "one of his all-time favorite covers" (Marsh and Callingham, "Foreword" 7)-and added his signature in the lower right corner.

10. The Cranbrook Art Museum in Bloomfield Hills, MI exhibited Warhol's collected record covers in 2014-2015 in the show "Warhol on Vinyl: The Record Covers, 1947-87." A brochure is available at http://www.cranbrookartmuseum.org/product/warhol-on-vinyl-the-recordcovers-1949-1987-gallery-guide/ (last visited Sept. 3, 2017).

11. As far as the jazz world was concerned, L.A. was in fact becoming more segregated than it had been in the 1940s. As Cawthra writes, "The Central Avenue entertainment district that had flourished until the mid-1940s had declined precipitously by the 1950 s. Supported by the surrounding (and rapidly growing) African American community, it had provided a home base in Los Angeles for musicians such as Howard McGhee, who led perhaps the first working bebop band in the city after leaving Coleman Hawkins's visiting group in 1945. It had also been a site of interracial youth culture for Asians and Latinos in addition to adventurous whites.... While the geography available for African Americans to inhabit in the area increased in the postwar years, the racial concentration in older settlements such as South Central increased, leading to an urban crisis in the years following the 1940s phase of the Great Migration. Police chief William Parker, while enjoying a favorable national reputation for cleaning up corruption within the Los Angeles Police Department, also presided over this hardening of racial lines" (174-175).

12. On the Way Out West cover, see also Michael Jarrett, "The Tenor's Vehicle: Reading Way Out West."

13. In the present context, the two most relevant later book publications are Young Chet (1993) and Steve McQueen (2004).

\section{ABSTRACTS}

In the early 1950s, American jazz entered a phase of artistic blossoming that was accompanied by widespread popularity and unprecedented cultural influence. By the late 1960s, however, this "second jazz age" had come to an end. This article draws on two approaches within cultural sociology to explain the historically specific cultural force of jazz: it follows American sociologist Howard S. Becker's method of reconstructing "art worlds," i.e., the networks of cooperation that include the institutional structures of marketing and distribution. In the jazz art world, the article suggests, sound becomes intermedially embedded in visual culture and textual repertoires. The essay also follows German sociologist Andreas Reckwitz, whose history of creativity allows for interpreting the impact of the jazz art world as a chapter in the rise of a creativity dispositif. In particular, this essay focuses on the photographic and illustrative work 
artists like William Claxton and Andy Warhol created for the newly emerging format of the record cover. The visual art of jazz helps account for jazz's ability to transport artistic hipness from the enclave of modernist art into the everyday.

\section{INDEX}

Keywords: Jazz, visual culture, LP cover art, record labels, art worlds, social aestheticization, creativity, cultural sociology, William Claxton, Andy Warhol, Howard S. Becker, Andreas Reckwitz

\section{AUTHOR}

\section{JOHANNES VOELZ}

Johannes Voelz is Heisenberg-Professor of American Studies, Democracy, and Aesthetics at Goethe-Universität Frankfurt. He is the author of Transcendental Resistance: The New Americanists and Emerson's Challenge (UP New England, 2010) and The Poetics of Insecurity: American Fiction and the Uses of Threat (Cambridge UP, 2018). He has moreover edited several collections of essays and special issues, among them Security and Liberalism, a themed issue of Telos (2015). In his preacademic past he worked as a freelance jazz critic for the Berlin daily paper Der Tagesspiegel and several magazines. 